
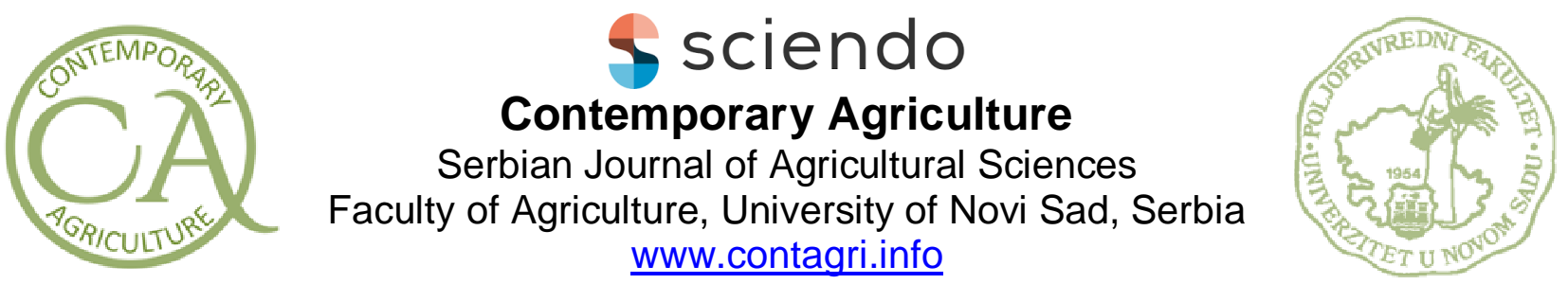

Original scientific paper

UDC: 637.1

DOI: $10.2478 /$ contagri-2020-0010

\title{
GENDER INVOLVEMENT OF SEDENTARY FULANI IN DAIRY FARMING PRACTICES IN OSUN STATE, NIGERIA
}

\author{
ABIODUN FAFOLARIN AGBOOLA, OMOLARA ADUKE OJO, MICHAEL FAMAKINWA*, \\ SHERIFF OLATUNJI WILLIAMS \\ Department of Agricultural Extension and Rural Development, Faculty of Agriculture \\ Obafemi Awolowo University, Ile Ife, Nigeria \\ *Corresponding author: famakinwamichael2013@gmail.com
}

\begin{abstract}
SUMMARY
The study assessed the gender involvement of sedentary Fulani in dairy farming practices in Osun State, Nigeria. A multi-stage sampling procedure was used to select 256 respondents from 12 Local Government Areas (LGAs) inhabited by the sedentary Fulani in the study area. Interview schedules were used for quantitative data collection. Data were analyzed and interpreted using descriptive statistics such as frequency counts, percentages, means and standard deviations while one-way ANOVA was used to draw inferences on the hypothesis. The results showed that the mean age of the male and female respondents was $34.05 \pm 12.49$ years and $33.33 \pm 13.14$ years respectively. The majority of the male $(85.9 \%)$ and female $(89.8 \%)$ respondents had no formal education. The mean herd size of male and female respondents was $20 \pm 2$ and $5 \pm 2$ heads of cattle respectively. All of the male respondents indicated that fencing, grazing and milking were male gender roles, while all female respondents indicated that cleaning of pens, sales of milk/milk products and processing of milk were female gender roles. The study showed that $42.7 \%$ of the male and $10.2 \%$ of the female respondents had high level of involvement in dairy farming activities, while $24.7 \%$ of the male and $44.2 \%$ of the female respondents had low level of involvement. Further results revealed that there were significant differences $(F=312.80)$ between the male and female respondents in their involvement in dairy farming practice. The study concluded that there is gender gap in male and female involvement in dairy farming practices.
\end{abstract}

Key words: gender gap, involvement, sedentary Fulani, dairy farming practices

\section{INTRODUCTION}

Livestock is generally considered as the dominant agricultural activity in Africa, sustaining most rural livelihood and food security (Assan, 2014). In Nigeria, agriculture accounted for $22.07 \%$ of the nominal Gross Domestic Product (GDP) in the fourth quarter of 2014, and livestock production grew by $12.7 \%$ (National Bureau of Statistics, 2014). Lombin (2011) and Bala et al. (2011) reported that Nigeria has a livestock population of about 16.3 million cattle, 40.8 million goats, 2.7 million sheep and 151 million poultry. Declining in the supply of cattle over the past two decades has been attributed to environmental hazards, while the demand has been increasing due to increase in population, high rate of urbanization and social activities. In Nigeria, ruminant livestock provide substantial quantities of animal protein. Livestock is mostly owned by pastoralists. Fulani are the largest nomadic group in the world (UNESCO, 2000). More than 80\% of the Nigerians depend on the pastoral Fulani for livestock consumption. Iro (1994), as cited in Salia-Bao (2017), reported that the Nigerians depend on the pastoral Fulani because they were custodians of herds providing meat, milk, ghee, cheese, wool, honey, butter, manure, incense, animal bloodspot products, and hides and skins to the nation. In the villages, Fulani are responsible for supplying the bulls used for carting, ploughing, and hauling. Salia-Bao (2017) reported that in the recent past dairy farming has increasingly become an important source of livelihood for sedentary Fulani found in the urban and peri-urban areas of Nigeria. 
Gender is particularly important when considering the socio-economic and marketing aspects of dairy farming. In many dairy farming scenarios, women are customarily involved in milk processing while men are involved in grazing and milking, so gender roles are differentiated in dairy farming practices. Food and Agriculture Organisation (FAO) (2004) defined gender as the relation between men and women, both perceptual and material. Gender roles are considered as the social definition of women and men in a society, so these roles can vary among different societies with regard to religion, culture, classes, values and beliefs (FAO, 1997). Contribution of women is vital in the food production systems of agriculture and dairy farming. Thousands of women have been working in the dairy industry throughout history and across nations. Their role differs across dairy industries, communities, countries and regions. Gender involvement clarifies gender roles within a community and how they affect the lives of men and women as well as their influence on development cooperative projects (World Bank, 1996). It also focuses on understanding and documenting the differences in gender role activities, needs and opportunities in a given situation. Gender roles in dairying are considered as the social definitions of women and men. Labour contribution in dairy production varies among gender for different activities.

FAO (2013) stated that men's and women's tasks and responsibilities were often given in rural societies based on traditional gender roles which they considers as specific and appropriate roles for male and females. According to FAO (2013), these roles are changing over time and in every local context they have different characteristics which are shaped by ideological, religious, cultural, ethnic and economic factors. FAO (2010) cited in FAO (2013), further explained that despite women's involvement and contribution to livestock production, their access to resources, extension services and participation in decision making are limited compared to male counterparts. This is as a result of gender discrimination against women due to traditional perception and structures that exist in rural settings which hinder them from obtaining necessary tools to fully maximize their potentials in agriculture (FAO, 2013).

Previous scholars, such as Okorie (2009) and Iro (2004), studied the sedentary Fulani in general. However, little attention was devoted to men and women's role, participation, responsibilities and privileges in dairy farming practices, hence the need for this study. The study was conceived to assess the involvement of male and female sedentary Fulani in the dairy farming practices, while the specific objectives were to gender-disaggregate the socioeconomic characteristics of dairy farmers; identify gender specific roles in dairy farming practices; and determine the level of involvement of the males and females in dairy farming practices in the study area. The hypothesis tested for this study was that there is no significant difference between male and female respondents in their involvement in dairy farming practices.

\section{MATERIAL AND METHODS}

The study was conducted in Osun State, Nigeria. The Fulani (sedentary) are found scattered all over the twelve Local Government Areas of the state, which are Ife North, Ede South, Ede North, Egbedore, Osogbo, Irewole, Atakumosa, Orolu, Olorunda, Odo-otin, Ayedire and Ejigbo (Torimiro, 2006).The Fulani live together in a cluster of tents called "Gaa Fulani". The study sample was drawn from Fulani settlements in Osun State using a multistage sampling procedure. The study covered three agricultural zones (ADP) of Osun State, which are Ife-Ijesa, Osogbo and Iwo zones. At the first stage, all 12 Local Government Areas (LGAs) occupied by the sedentary Fulani were purposively selected for the study. At the second stage, $20 \%$ of the Fulani settlements were proportionately selected from 160 Fulani Settlement across the selected LGAs, making a total of 32 settlements in all. At the third stage, two households were randomly selected from each of the 32 Fulani settlements, making a total of 64 households. At the final stage, four respondents (comprising an adult male, an adult female, a youth male and a youth female) were randomly selected from each of the households. In total, two hundred and fifty six (256) respondents were selected for the study. A structured interview schedule was used to obtain quantitative data, while in-depth interview guide was used to obtain qualitative data. The data obtained was summarized using descriptive statistical tools such as frequency counts, percentages, means standard deviations, bar and pie charts while one-way ANOVA was used to draw inferences on the hypothesis. Dependent variable for the study was involvement, which refers to the extent of participation in various identified practices. Gender mapping tool was used to elicit information on gender involvement at each stage of the processing. Gender mapping tool according to Deji et al. (2012) is assignment of positions and roles to males and females based on the prevailing socio-cultural traditions of norms and values in the society along a continuum or a process. This can be used to elicit information on involvement (participation), resources, decision making among male and female respondents. Available and common dairy farming practices were listed and the respondents were asked to indicate their involvement in dairy farming practices on a four-point scale which was scored as follows: not involved $=0$, rarely involved $=1$, sometimes involved $=2$, regularly involved 
$=3$. The total score obtained for each respondent was categorized into high, medium and low using mean plus or minus standard deviation.

\section{RESULTS AND DISCUSSION}

\section{Socio-economic characteristics of the respondents}

The results in Table 1 show that the mean age of the male and female respondents was $34.05 \pm 12.50$ years and 33.33 \pm 13.14 years respectively. The result implies that the respondents were in young and still in their active age. This is similar to the findings of Adeyemo (2017), who reported that the mean age of the male and female Fulani involved in dairy value chain in Oyo State was $32.52 \pm 0.11$ years and $30.73 \pm 0.13$ years respectively. These activities are the basic features of nomadism for achieving their economic and cultural survival. This is also in consonance with the studies of Adedoyin et al. (1997) and Adedoyin et al. (1999), who reported that at an early age, children are interested and satisfied with farming, but as they are growing older their interest is waning and they become dissatisfied; hence, their involvement reduces with age. The results in Table 1 show that the majority of the male and female respondents $(80.5 \%$ and $78.1 \%$ respectively) were married. This result is in agreement with Iro (2004), who notes that the culture of Fulani forbids divorce. Traditionally, married people are highly respected and valued, seen as responsible individuals while divorce is culturally a rare occurrence (Babatunde, 2004). Also, $100 \%$ of both male and female respondents were Muslims. The sedentary Fulani are predominantly Muslims. This finding agrees with previous studies which also reported all respondents to be Muslim (Torimiro et al., 2003; Adedoyin et al., 1997). Further results show that monthly income of the male respondents was the mean income of $1157,986.65 \pm \$ 58,123$, while that of the female respondents was $\$ 48,299.22 \pm 5,311.66$. This implies that the males earn higher income than that of their female counterparts. This is due to the fact that the male respondents have full control and access to the sales of cattle (bulls) which generates higher income, while the females mostly earn their income from the sale of milk and milk products (Waters-Bayer, 1988).

The mean herd size for the male and female sedentary Fulani was $20 \pm 2.3$ and $5 \pm 3$ cattle respectively as shown in Table 1, indicating that the males had higher herd size than their female counterparts. This result confirms the findings of Njuki and Mburu (2013) that men owned a significantly higher number of head of cattle than women in Eastern and Southern Africa. Also, Assan (2014) asserted that gender-based inequalities often result in women's and girls' having limited access to large ruminants especially cattle; women face a variety of gender-based constraints as members of the household in terms of ownership of livestock. This is due to the fact that female Fulani do not have much access to cattle, as the ones they have are gift from their parents during marriage or offspring of that cattle. This finding gives credence to the submission of Adholla-Migot \& Little (1980) who reported that Fulani women were in charge of the local dairy production in Nigeria, although they owned only a few of the family's cattle. The majority of the male $(76.6 \%)$ and female (75\%) respondents had no formal education, while few $(9.4 \%$ and $14.8 \%$ respectively) had koranic education. This shows that their level of education is still very low despite the effort of the government to reduce the level of illiteracy. This is in line with the findings of Okorie (2009), and Iro (2004) who posited that virtually all the cattle rearers found in the rural areas do not have formal education. This could be based on the report of UNESCO (2003) which established that cattle rearing is time consuming and does not give room for school enrolment. Further analysis shows that higher proportion of the female respondents owned local poultry and sheep $(67.2 \%$ and $56 \%$ respectively) than male counterparts where few owned local poultry and sheep (4.7\% and $25 \%$ respectively). Also, the majority of the male respondents $(85.9 \%)$ owned goats, while only few of female respondents (25\%) owned goats. This finding gives credence to the results of Njuki \& Mburu (2013) that ownership of local chickens was higher among women than men but contradict the finding that more women owned goats than men in Kenya, Tanzania and Mozambique. The majority of male respondents (67.3\%) had contact with extension agents while few of the female respondents (27.3\%) had contact with extension agents. This shows that female respondents had low contact with extension agents due to their culture and religion of Fulani people.

Table 1. Socio-economic characteristics of respondents

\begin{tabular}{lllll}
\hline Variables & Male & \multicolumn{3}{c}{ Female } \\
& Frequency & Percentage & Frequency & Percentage \\
\hline Age (years) & & & & \\
$<16$ & 9 & 6.7 & 12 & 9.4 \\
$16-30$ & 55 & 43.3 & 53 & 41.4 \\
$31-45$ & 36 & 28.1 & 38 & 29.7 \\
$>45$ & 28 & 21.9 & 25 & 19.6 \\
\hline Mean \pm S.D & $34.05 \pm 12.5$ & & $33.33 \pm 13.15$ & \\
\hline
\end{tabular}




\begin{tabular}{|c|c|c|c|c|}
\hline \multicolumn{5}{|l|}{ Marital status } \\
\hline Married & 25 & 19.5 & 28 & 21.9 \\
\hline Single & 103 & 80.5 & 100 & 78.1 \\
\hline \multicolumn{5}{|l|}{ Family type } \\
\hline Monogamy & 0 & 00 & 0 & 00 \\
\hline Polygamy & 128 & 100 & 128 & 100 \\
\hline \multicolumn{5}{|l|}{ Religion affiliation } \\
\hline Islam & 128 & 100 & 128 & 100 \\
\hline Christianity & 0 & 0 & 0 & 0 \\
\hline Traditional & 0 & 0 & 0 & 0 \\
\hline \multicolumn{5}{|l|}{ Household size( person) } \\
\hline$<6$ & 10 & 7.8 & 13 & 10.2 \\
\hline $6-12$ & 87 & 68 & 77 & 60.2 \\
\hline $13-18$ & 29 & 22.7 & 35 & 27.3 \\
\hline$>18$ & 2 & 1.6 & 3 & 2.3 \\
\hline Mean $\pm S . D$ & \multicolumn{2}{|c|}{$10 \pm 3$} & \multicolumn{2}{|c|}{$10 \pm 3.2$} \\
\hline \multicolumn{5}{|l|}{ Place of Birth } \\
\hline Host community & 102 & 79.7 & 99 & 77.3 \\
\hline Outside community & 26 & 20.3 & 29 & 22.7 \\
\hline \multicolumn{5}{|l|}{ Monthly income } \\
\hline$<® 100,000$ & 66 & 51.6 & 128 & 100 \\
\hline$\# 100,000-\# 300,000$ & 31 & 24.2 & 0 & 0 \\
\hline$\# 300,001-\$ 400,000$ & 29 & 22.6 & 0 & 0 \\
\hline$¥ 400,001-\# 600,000$ & 2 & 1.6 & 0 & 0 \\
\hline Mean \pm S.D & \multicolumn{2}{|c|}{$157,986.65 \pm 58,123$} & \multicolumn{2}{|c|}{$48,299.21 \pm 0.00$} \\
\hline \multicolumn{5}{|l|}{ Other occupation } \\
\hline Arable farming & 103 & 80.5 & 10 & 7.8 \\
\hline Petty trading & 10 & 7.8 & 100 & 88.1 \\
\hline Hunting & 10 & 7,8 & 0 & 0 \\
\hline Artisan & 5 & 3.9 & 18 & 14.1 \\
\hline \multicolumn{5}{|l|}{ Herd Size } \\
\hline$\leq 10$ & 35 & 27.3 & 126 & 98.4 \\
\hline $11-20$ & 41 & 32.0 & 2 & 1.6 \\
\hline $21-30$ & 26 & 20.3 & 0 & 0 \\
\hline $31-40$ & 12 & 9.4 & 0 & 0 \\
\hline $41-50$ & 12 & 9.4 & 0 & 0 \\
\hline$\geq 50$ & 2 & 1.6 & 0 & 0 \\
\hline Mean/S.D: & \multicolumn{2}{|c|}{$19.98 \pm 2.33$} & \multicolumn{2}{|c|}{$5.30 \pm 2.14$} \\
\hline \multicolumn{5}{|l|}{ *Other livestock reared } \\
\hline Poultry & 6 & 4.70 & 86 & 67.2 \\
\hline Sheep & 32 & 25.0 & 72 & 56.0 \\
\hline Goat & 110 & 85.9 & 32 & 25.0 \\
\hline \multicolumn{5}{|l|}{ Highest education level } \\
\hline No formal education & 98 & 76.6 & 96 & 75.0 \\
\hline Koran education & 12 & 9.4 & 19 & 14.8 \\
\hline Adult education & 11 & 8.6 & 10 & 7.8 \\
\hline Pry/sec. education & 7 & 5.5 & 3 & 2.3 \\
\hline
\end{tabular}

\section{Gender specific roles in dairy farming practices}

The results in Table 2 show that all of male respondents (100\%) claimed that the following roles in dairy farming were male gender roles they performed: construction/fencing, feeding/grazing of animals, watering, tethering, milking, culling/isolation of sick animals, diagnosing, vaccination, sales of bull/calf, picking of ticks and dehorning. Also other roles that the male respondents indicated that they performed were salting (99.2\%), taking sick animals to veterinary doctor $(84.4 \%)$, castration $(63.3 \%)$ and cleaning of pens $(0.8 \%)$. However, $100 \%$ of the female respondents claimed that cleaning of pen, sales of milk/milk product and processing of milk were female gender roles which they performed. Also, cow dung (90.6\%), sale (63.3\%), salting, $(48.4 \%)$, sale of bull/calf (48.4\%), watering (19.5\%), picking of ticks (14.8\%) and feeding (10.2\%) were other roles which the Fulani women indicated that they performed. This implies that more roles and responsibilities were attached to Fulani men than women because of socio-cultural biases. This finding is in line with Dixon (1982) assertion that the roles women played in 
farming and livestock are not formally recognized. Castration and vaccination were newly introduced practices, and not all Fulani are involved in these practices but castration was mostly done for male cattle that are meant for sale. Among the Fulani of Nigeria, women were responsible for milk processing and marketing but do not milk the animals or have control over such decisions as the selection of grazing sites, length of the grazing day, supplementation of cattle diets, when to begin milking after birth, how much milk to leave for calves, breeding and veterinary care - all of which influence milk production. Women are entitled to receive milk from the herd but have little influence on the quantity given, unless the animals are owned by the women or their children. Once the milk is received, a woman is free to decide how to allocate it (Waters-Bayer, 1985).

Table 2. Gender specific roles in dairy farming practices

\begin{tabular}{lllll}
\hline Practices & Male & \multicolumn{3}{r}{ Female } \\
& Frequency & Percentage & Frequency & Percentage \\
\hline Construction/fencing & 128 & 100.0 & 0 & 0 \\
Feeding/grazing & 128 & 100.0 & 13 & 10.2 \\
Watering & 128 & 100.0 & 25 & 19.5 \\
Salting & 127 & 99.2 & 81 & 63.3 \\
Cleaning of pen/cage & 1 & 0.8 & 128 & 100.0 \\
Tethering & 128 & 100.0 & 0 & 0 \\
Milking & 128 & 100.0 & 0 & 0 \\
Culling/isolation & 128 & 100.0 & 0 & 0 \\
Diagnosing & 128 & 100.0 & 0 & 0 \\
Vaccination & 128 & 100.0 & 0 & 0 \\
Bringing sick animals to vet & 108 & 84.4 & 0 & 0 \\
Castration & 81 & 63.3 & 0 & 0 \\
Branding & 0 & 0 & 0 & 0 \\
Sales of bull/calf & 128 & 100.0 & 62 & 48.4 \\
Sales of cow dung & 0 & 0 & 116 & 90.6 \\
Sales of milk/milk product & 0 & 0 & 128 & 100.0 \\
Processing of milk & 0 & 0 & 128 & 100.0 \\
Record keeping & 0 & 0 & 0 & 0 \\
Picking of ticks & 128 & 100.0 & 19 & 14.8 \\
Dehorning & 128 & 100.0 & 0 & 0 \\
\hline Source: Field Survey, 2018 & & & &
\end{tabular}

\section{Gender involvement in dairy farming activities}

The mean score in descending order of involvement was used to determine the involvement of the males and females in dairy farming. The results in Table 3 shows that the grand mean scores of the male and female respondents in dairy farming were 1.38 and 0.68 respectively. This implies that the majority of the male respondents were more involved in dairy practices than their female counterparts. This might be due to the fact that most of the practices were male dominated. Sales of bull/calf (mean=2.97) ranked highest among the male respondents. This is in line with the findings of FAO (2011) that reported that men were responsible for taking decisions related to the sale of animals even if they were owned by their wives. This was followed by feeding $(\operatorname{mean}=2.55)$, diagnosing $($ mean $=2.40)$, vaccination $(m e a n=2.34)$, castration $(m e a n=2.34)$, milking $(m e a n=2.19)$, construction/fencing (mean=2.18), isolation/culling (mean=2.18) in that order. On the other hand, the activity that ranked highest among dairy farming practices for the female respondents was processing of milk (mean=2.72). This is followed by sales of cow dung (mean=2.39), cleaning of pen (mean $=2.16$ ), sales of milk and milk products (mean=1.60), picking of ticks (mean=1.16), feeding of animals (mean=1.00), watering of animals (mean=0.59). This is in line with the results of Waters-Bayer (1985) and Dieye et al. (2005) who reported that women are mostly responsible for milk processing and marketing of milk and milk products in the village markets but have no control over milking of the animals. The results show that the majority of the male respondents were mostly involved in dairy activities that were male gender-specific activities such as castration, dehorning, vaccination, diagnosing of disease, milking, tethering and isolation/culling of sick animals; these results could be due to the fact that most of these activities need special veterinary skills which are readily available to men while women either lack them or are afraid to perform the activities (FAO, 2013). Also, these are highly risky and strenuous activities that require a lot of energy to carry out. On the other hand, most of the female respondents were mostly involved in practices that are less risky, supportive and easy to practise, which are female gender-specific activities such as processing of milk and milk products, sales of cow dung, cleaning of pens, sales of milk/milk products (Waters-Bayer, 1985; Dieye et al., 2005). This gives 
credence to the results of Laven et al. (2009) and Coles \& Mitchell (2011) as cited in Assan (2014) that limited participation of rural women in livestock value chain activities results from fundamental misunderstanding of gender relationships, socio-economic and cultural roles in livestock production at the household and community levels. The results also indicated that both male and female respondents were not involved in record keeping, which is an important dairy management activity that could assist their productivity and efficiency.

Table 3. Gender involvement in dairy farming practices

\begin{tabular}{lllll}
\hline Dairy activities & $\begin{array}{l}\text { Male } \\
\text { means }\end{array}$ & Rank & $\begin{array}{l}\text { Female } \\
\text { means }\end{array}$ & Rank \\
\hline Construction/fencing & 2.18 & $8^{\text {th }}$ & 0 & $11^{\text {th }}$ \\
Feeding & 2.55 & $2^{\text {nd }}$ & 1.00 & $7^{\text {th }}$ \\
Watering & 1.94 & $12^{\text {th }}$ & 0.59 & $8^{\text {th }}$ \\
Salting & 1.94 & $12^{\text {th }}$ & 0.04 & $10^{\text {th }}$ \\
Cleaning of pen/cage & 0 & $16^{\text {th }}$ & 2.16 & $3^{\text {rd }}$ \\
Tethering & 2.18 & $8^{\text {th }}$ & 0 & $11^{\text {th }}$ \\
Milking & 2.19 & $7^{\text {th }}$ & 0.46 & $9^{\text {th }}$ \\
Culling/isolation & 2.18 & $8^{\text {th }}$ & 0 & $11^{\text {th }}$ \\
Diagnosing & 2.40 & $3^{\text {rd }}$ & 0 & $11^{\text {th }}$ \\
Vaccination & 2.34 & $4^{\text {th }}$ & 0 & $11^{\text {th }}$ \\
Bringing sick animals to vet & 2.18 & $8^{\text {th }}$ & 0 & $11^{\text {th }}$ \\
Castration & 2.34 & $4^{\text {th }}$ & 0 & $11^{\text {th }}$ \\
Sales of bull/calf & 2.97 & $1^{\text {st }}$ & 1.46 & $5^{\text {th }}$ \\
Sales of cow dung & 0 & $16^{\text {th }}$ & 2.39 & $2^{\text {nd }}$ \\
Sales of milk/milk product & 0 & $16^{\text {th }}$ & 1.60 & $4^{\text {th }}$ \\
Processing of milk & 0 & $16^{\text {th }}$ & 2.72 & $1^{\text {st }}$ \\
Record keeping & 0 & $16^{\text {th }}$ & 0 & $11^{\text {th }}$ \\
Picking of ticks & 1.52 & $14^{\text {th }}$ & 1.16 & $6^{\text {th }}$ \\
Dehorning & 0.94 & $15^{\text {th }}$ & 0 & $11^{\text {th }}$ \\
Branding & 0 & $16^{\text {th }}$ & 0 & $11^{\text {th }}$ \\
Grand mean & 1.38 & & 0.68 & \\
\hline Source: Field Survey, & & & & ${ }^{2018}$ \\
\hline
\end{tabular}

Source: Field Survey, 2018

\section{Level of involvement of males and females in dairy farming practices}

Figure 1 shows that below half of the male respondents (42.7\%) had high level of involvement, while few of female respondents $(10.7 \%)$ had high level of involvement in dairy farming activities; almost one-third of male (32.6\%) and one-third of female respondents $(35.2 \%$ ) had moderate level of involvement in dairy activities, while $24.7 \%$ of male and less than half of of female respondents $(44.3 \%)$ had low level of involvement in dairy activities in the study area. The results show that there is gender gap in the level of involvement in dairy farming activities as more male Fulani were involved in dairy farming activities compared to the females. The possible explanation is that most of the dairy activities are male gender-specific activities, while few activities are female gender-specific, and only few of the women were highly involved in them. This buttresses the report of Assan (2014) that in developing countries the role of women who are involved in livestock production has been limited by socio-economic and cultural biases which hinder them from fulfilling their responsibilities and/or striking the right balance with men when carrying out livestock responsibilities.

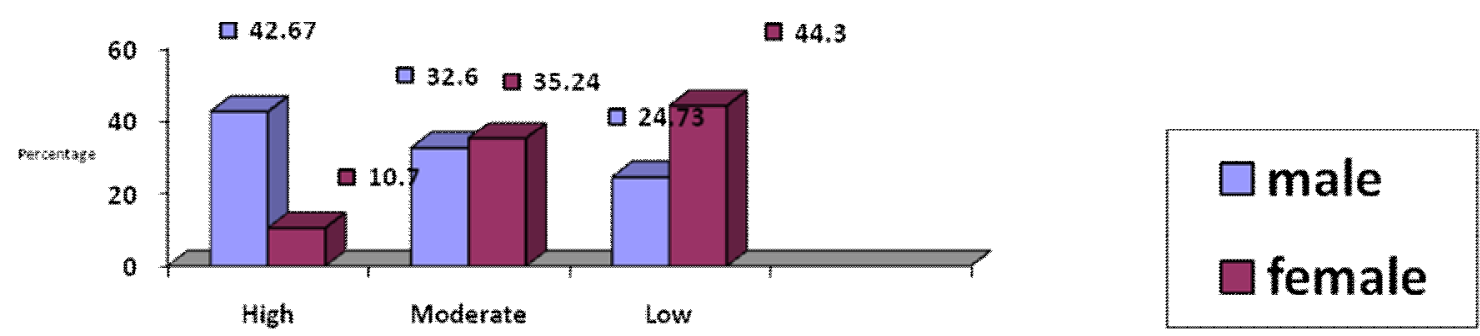

Figure 1. Bar chart showing level of gender involvement in dairy farming practices 


\section{Difference between male and female level of involvement in dairy farming activities}

Results of one-way ANOVA in Table 4 show that there was significant difference $(\mathrm{F}=312.80)$ in involvement in dairy farming practices between male and female sedentary Fulani at 0.01 level of significance. This result implies that there is gender gap between the male and female respondents in relation to their involvement in dairy farming practices. It could be as a result of different roles allocated to gender as most of these roles/activities were male dominated. This finding is similar to findings by Umar et al. (2010), who showed that men were more involved in most agricultural activities than women.

Table 4. Analysis of variance of respondents' involvement in dairy farming practices

\begin{tabular}{|c|c|c|c|c|c|}
\hline Involvement & $\begin{array}{l}\text { Sum of } \\
\text { Squares }\end{array}$ & $\begin{array}{l}\text { Degree of } \\
\text { Freedom }\end{array}$ & Mean Square & $\mathrm{F}$ & p-value \\
\hline Between group & 21793.14 & 1 & 21793.14 & & \\
\hline Within group & 17696.30 & 254 & 69.67 & 312.80 & 0.00 \\
\hline Total & 39489.44 & 255 & & & \\
\hline
\end{tabular}

\section{CONCLUSION}

The study concluded that there was gender gap in dairy farming practices as most of the activities were maledominated. It was observed that the majority of the respondents involved in dairy farming activities were males, while their female Fulani counterparts gave supportive services such as cleaning, processing of milk and sales of animal products. Based on the findings of this study, it is therefore recommended that intervention in the dairy sector should be aimed at filling the gender gap related to participation in dairy farming practices by encouraging more involvement of the Fulani women in dairy farming activities. The government should also make gender sensitive production policies that would acknowledge gender needs and priorities of Fulani men and women to facilitate more gender equitable opportunities that will ensure maximum production. The State government should employ adequate number of male and female livestock extension agents to enhance effective dissemination of appropriate dairy technologies to the pastoralists; and finally, capacity building and trainings should be organized for both male and female Fulani in order to enhance development of the dairy sector in Nigeria.

\section{REFERENCES}

Adedoyin S.F., Torimiro D.O., Fagbemi O.O., (1997): Need perception of nomadic Falbe Herdsmen in Upper Ogun, In: Proceedings of the third annual conference of Agricultural Extension Society of Nigeria, $4^{\text {th }}-6^{\text {th }}$ March, Obafemi Awolowo University, Agricultural Extension Society of Nigeria, pp. 124-129.

Adedoyin S.F., Torimiro D.O., Farinde A.J. (1999): Food Security in the 21st century: the Children in Agriculture Programme (CIAP) as an extension communication strategy for continuity and sustainability. In: Poverty alleviation and food security in Nigeria. Nig. Association of Agric. Economists.

Adeyemo A.R. (2017): Gender involvement in the traditional and transformed dairy value chains in Oyo State, Nigeria. An unpublished M.Sc. thesis in the department of Agricultural Extension and Rural Development, Obafemi Awolowo University, Ile-Ife, Nigeria.

Adholla-Migot S. \& Little P. (1980): Evolution of Policy toward the Development of Pastoral Areas in Kenya. In: The Future of Pastoral People: Proceedings of a Conference Held in Nairobi, August 4-8, 1980, Institute of Development Studies. Nairobi: Institute of Development Studies, pp. 144-153.

Assan N. (2014): Gender disparities in livestock production and their implication for livestock productivity in Africa. Scientific Journal of Animal Science, 3(5):126-138, doi: 10.14196/sjas.v3i5.1366.

Babatunde E. (2004): Traditional marriage and family. In: Understanding Yoruba Life and Culture. N.S. Lawal, M.N.O. Sadiku, P.A. Dopemu (Ed). Africa World Press Inc.

Bala A., Ali G., Adamu Y. (2011): Bacterial and parasitic zoonoses encountered at slaughter in Maiduguri abattoir, Northeastern Nigeria, Veterinary World, 4(10): 437-443.

Coles C. \& Mitchell J. (2011): Gender and Agricultural Value Chains, a review of currentknowledge and practice and their policy implications, ESA Working Paper $\mathrm{N}^{\mathrm{O}}$ 11-05, Agricultural Development Economics Division, FAO.

Deji O.F, Owombo P.T, Koledoye G.F (2012): Impacts of training in Oil Palm processing technologies among Small scale farmers in Ondo State, Nigeria. Journal of Agriculture and Biodiversity Research, 85-90.

Dieye P.N., Ly C., Sane F.C.N. (2005): Etude des service d'élevage dans la fi lière laitere au Sénégal. Pro-Poor Livestock Policy Initiative (PPLPI) Internal Report, Rome, FAO.

Dixon R.B. (1982): Women in agriculture: Counting the labor force in developing countries. Population Development Review, 8(3): 539-565.

FAO (1997): Gender: the key to sustainability and food security. SD Dimensions, May 1997 (available at $\underline{w w w . f a o . o r g / s d) . ~}$ 
FAO (2004): Food and Agriculture Organization - Building on Gender, Agrobiodiversity and Local Knowledge”. Training Manual Rome, Italy, Available at: http://www.fao.org/3/y5608e/y5608e00.htm

FAO (2010): Food and Agriculture Organization - Roles of women in agriculture. Available at: http://www.fao.org/docrep/013/am307e/am307e00.pdf

FAO (2011). The State of Food and Agriculture (SOFA) 2010-2011- Women in agriculture: Closing the gender gap for development Food and Agricultural Organization of the United Nations. Available online at http://www.fao.org/docrep/013/i2050e/i2050e00.htm

FAO (2013): Food and Agricultural Organisation - Understanding and Integrating Gender Issues into Livestock Projects and Programmes, A checklist for Practitioners. Food and Agriculture Organization, Rome. Available at: http://www.fao.org/publications/card/en/c/c82d93c8-370e-5413-be14-1ef008ff898a/

Iro H.I. (1994): From Nomadism to Sedentarism an Analysis of Development Constraints and Public Policy Issues in the Socioeconomic Transformation of the Pastoral Fulani of Nigeria. Ph.D. thesis, Howard University.

Iro H.I. (2004): The Fulani milk maid and problems of dairying in Nigeria. Available at: www.gamji.com/fulanill.htm

Laven A., Van Eerdewijk A., Senders C., Van W., Snelder R. (2009): Gender in value chains: Emerging lessons and questions, KIT, CIDIN, HIVOS, Agri-Pro-Focus and ICCO, 1-13.

Lombin L. (2011): National Veterinary Research Institute, Jos. Annual National Conferences paper presented at Abuja. 20.

National Bureau of statistics (NBS) (2014): Nigerian gross domestic product report, Fourth Quarter 2014. Available at: https://www.nigerianstat.gov.ng

Njuki J. \& Mburu S. (2013): Gender and Ownership of Livestock Assets in Women, Livestock Ownership and Markets Bridging the Gender Gap in Eastern and Southern Africa, Routledge New York, International Development Research Centre, Canada. pp. 27-28.

Okorie V.O. (2009): Participation of sedentary Fulani youths in community development activities in Osun State, Nigeria. M. Phil Agric. Ext. and Rural Sociology Thesis, Obafemi Awolowo University, Ile-Ife, pp. 188-190.

Salia-Bao K. (2017): An Analytical Study of Nomadic Education and Culture among the Fulanis in West Africa. Journal of Academic Perspectives, 3: 1-24

Torimiro D.O. (2006): Ehno-cultural Relation and Nomaic Youth Identity Transformation among the Fulani Settlers in Osun State", Technical Report for CODESIRA.

Torimiro D.O., Dionco-Adetayo E., Okorie V.O. (2003): Children and Involvement in Animal Rearing: A Traditional Occupation for Sustainability of Nomadic Culture? Early Child Development and Care, 173(2-3): 185-191.

Umar H.S., Luka E.G., Rahman S.A. (2010): Gender based analysis of labour productivity in sesame production in Doma Local Government of Nasarawa State. PPMT 6(2): 61-68.

UNESCO (2000): United Nations Educational, Scientific Cultural Organization - Courier Report: Nomadic Education in Senegal Available at: http://www.unesco.org /education/en/file/\%20download.php/u44c98d69

UNESCO) (2003): United Nations Educational, Scientific Cultural Organization - Inter-cultural Education. A United Nations Educational, Scientific Cultural Organization Conference held on June 15-18, Jyvaskyla, Finland, Europe.

Waters-Bayer A. (1985): Dairying by Settled Fulani Women in Central Nigeria and Some Implications for Dairy Development. ODI Pastoral Development Network Paper 20c. London: Overseas Development Institute.

Waters-Bayer A. (1988): Dairying by Settled Fulani Agropastoralists: The Role of Women and Implications for Dairy Development. Kiel: Vauk Wissenschaftsverlag.

World Bank (1996): World development Report. New York, Oxford University Press.

Submitted: 1.4 .2020 .

Accepted: 3.8.2020. 